\begin{tabular}{|c|c|c|}
\hline 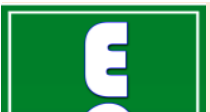 & $\begin{array}{l}\text { International Journal of Current Research in } \\
\text { Biosciences and Plant Biology }\end{array}$ & $m$ \\
\hline & Volume $7 \bullet$ Number 8 (August-2020) • ISSN: 2349-8080 (Online) & \\
\hline $\begin{array}{l}\text { EXCELLENT } \\
\text { PUBLISHERS }\end{array}$ & Journal homepage: $\underline{w w w . i j c r b p . c o m}$ & \\
\hline
\end{tabular}

\title{
Study of efficiency and control of paddy sheath blight and leaf blast by caliber fungicide
}

\author{
Nilesh Nalawade ${ }^{1}$, Amol Kumbhar ${ }^{*}$, Ashish Raskar¹ and Atul Baravkar² \\ ${ }^{1}$ College of Agriculture and Allied Sciences, Baramati, Pune, Maharashtra, India-413 115 \\ ${ }^{2}$ Shardabai Pawar Institute of Pharmaceutical Sciences and Research, Baramati, Pune, Maharashtra, India-413 115 \\ *Corresponding author; e-mail: atul200678@gmail.com
}

\begin{tabular}{|c|c|}
\hline Article Info & ABSTRACT \\
\hline $\begin{array}{l}\text { Date of Acceptance: } \\
29 \text { July } 2020\end{array}$ & \multirow{3}{*}{$\begin{array}{l}\text { A field research was conducted during spring season in } 2019 \text { at College of Agriculture, } \\
\text { Baramati (Maharashtra) to find out the Efficiency and Control of Paddy Sheath Blight } \\
\text { and Leaf Blast by Caliber (Natural Polysaccharide, Potassium, Phosphorus, Bio silicate, } \\
\text { Seaweed Extract and Solvent) under field condition and to study the on preventive and } \\
\text { curative activity of Caliber. The experiment was laid out in Randomized block design } \\
\text { with three replications. The four lot treatments comprised four, viz., T1 (Caliber @ } \\
2 \mathrm{ml} / \text { lit), T2 Caliber @ } 3 \mathrm{ml} / \text { lit), T } 3 \text { (Caliber @ } @ 4 \mathrm{ml} / \text { lit) and T } 4 \text { (control).Most of the } \\
\text { fungicides are developed and registered for management of diseases which develop on } \\
\text { aerial plant parts. Caliber is a microbial base fungicide. It is effective against oomycetes } \\
\text { group of fungi like Pythium, Pytophthora, and Plasmopara. }\end{array}$} \\
\hline Keywords & \\
\hline $\begin{array}{l}\text { Caliber } \\
\text { Fungicides } \\
\text { Disease } \\
\text { Pythium } \\
\text { Phythopthora }\end{array}$ & \\
\hline
\end{tabular}

\section{Introduction}

Pathogens respond to the use of fungicides by evolving resistance. In the field, several mechanisms of resistance have been identified. Most of these plant pathogens have an exceptional potential to reproduce within the plant host. For example, Pytophthora infestans can produce 50 ooo to 117 ooo sporangia per linear centimetre of infected potato stem length (Johnson et al., 2000). Considering the prevalence, ubiquitous nature and the ability of fungi and oomycetes to cause epidemics in relatively short period of time, disease management strategies are needed to secure the productivity in today's agriculture. Chemical control measures are particularly common in management of fungal plant diseases, and most of these measures rely on the use of fungicides. No matter of many differences in biology of different fungal and oomycetous plant pathogens, they share certain similarities. Most of the fungi produce various kinds of spores, which come in contact with plant tissue, germinate, and penetrate into the plant during the infection process. Some plant pathogenic fungi (e.g. leaf blast and sheath blight of paddy, Rhizoctonia solani, Sclerotium rolfsii, or Macrophomina phaseolina) rarely produce spores and infect plants through penetration of mycelia into plant tissue. Nearly all fungicides used in agriculture today show their best effect if applied before the infection occurs.. Movement and translocation of fungicides within the plant differs 
between various fungicide active compounds, and delineation between systemic and non-systemic fungicides is often not clear. Most of the true systemic fungicides translocate through the xylem, and relatively small number of them has an ability to translocate basipetally in the phloem (Jacob and Neuman, 1987). Some of the fungicides found on the market today are only locally mobile, translocating only within the organ of application (Jacob and Neuman, 1987).

\section{Materials and methods}

The field experiment was conducted at Agronomy Department Farm, College of Agriculture, Baramati. Dist. Pune during kharif season of season of 2016, 2017, 2018 respectively. The selection of the site was considered on the basis of availability of land, suitability of climate for disease incidence, availability of skilled labour, etc. The gross and net plot size is $-4 \mathrm{~m} \times 3.75 \mathrm{~m}$ and $3.60 \mathrm{~m}$ $\times 3.45 \mathrm{~m}$ respectively. The verity of paddy grown in experimental plot is IR-64. The soil type for research plot is medium black. The quantity of fungicides dose was calculated as per the treatments and applied in the plots as per the treatments after the incidence of disease at certain interval. Fungicides are applied in the form of spraying on paddy crop to minimize the intensity of diseases.

\section{Results and discussion}

Fourteen days after the fungicidal application disease assessment was carried out. The disease was measured using the disease rating scale of $0-9$ developed by International Rice Research Institute (IRRI, 1996) for sheath blight and blast disease. Further the scored data was converted into percent disease severity using the formula given bellow. Subsequently, the data on disease severity was subjected to appropriate statistical analysis.

$$
\text { Disease severity } \%=\frac{\text { Average score } \times 100}{\text { Maximum score }}
$$

Sheath blight ( $R$. solani) infection dominated during all the years. The infection was severe in second and third season.

Table 1. Efficacy of fungicide Caliber as prophylactic spray against $R$. solani under field conditions.

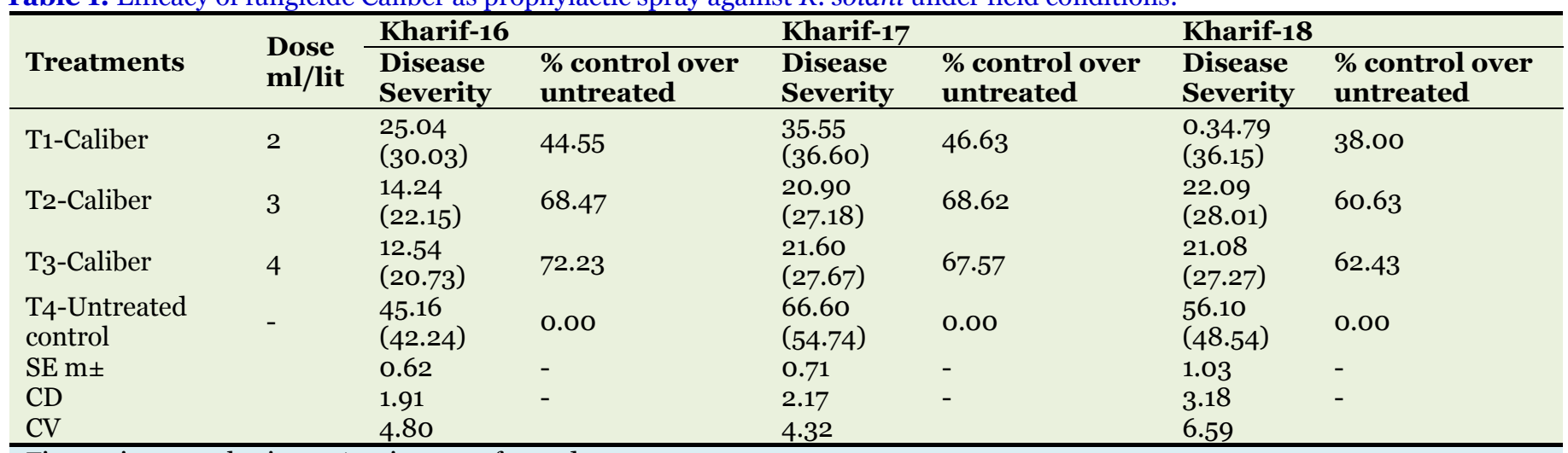

Figures in parenthesis are Arcsine transformed.

During the study, disease severity was $45.16,66.60$ and 56.10 in untreated control duringKharif-16, Kharif-17 and Kharif-18 respectively. The increased disease pressure in the present study was attributed to high humidity and intermittent rains. In all the three seasons, Caliber provided excellent control of sheath blight with exceptional longlasting activity against sheath blight. Caliber @ 3 and $4 \mathrm{ml} /$ lit was found highly effective as prophylactic spray with per cent disease severity (14.24 and $12.54 \%$ ) and per cent control over untreated was registered as 68.47 and 72.23, respectively during Kharif-16. The untreated plots recorded $45.16 \%$ disease severity, which confirms the disease pressure during the experimentation. Similarly, during Kharif-17 and Kharif-18, Caliber @ 3 and $4 \mathrm{ml} /$ lit recorded a disease control 68.62 and $67.57,60.63$ and $62.43 \%$, respectively over untreated (Table 1). The disease severity in untreated plots was higher compare to Kharif-16 which recorded 66.60 and $56.10 \%$, respectively in Kharif-17 and Kharif-18. The mean result proved that fact that Caliber can give good control of the disease as protective fungicide. 
Table 2. Impact of Fungicide Caliber as curative spray rice sheath blight disease

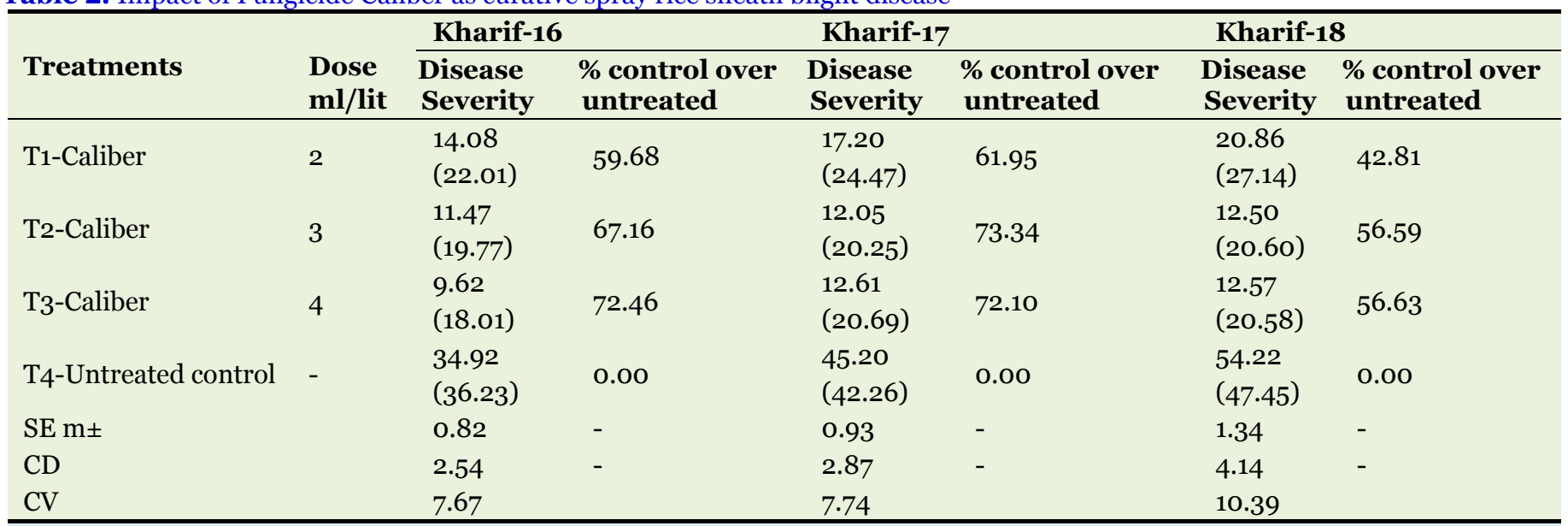

Figures in parenthesis are Arcsine transformed.

As the data presented in Table 2, the Caliber sprayed after appearance of the disease symptoms exhibited good control of the sheath blight. Consistent results were observed in all the three seasonal trials with application of Caliber @ 3 and 4 $\mathrm{ml} /$ lit recorded 11.47 and 9.62, 12.05 and 12.61, 12.50 and 12.57 during Kharif-16, Kharif-17 and Kharif-18 respectively. The disease severity in untreated plots was higher compare to fungicide application recorded 34.92, 45.20 and 54.22\%, respectively in Kharif-16, Kharif-17 and Kharif-18. Caliber @ 3 and $4 \mathrm{ml} /$ lit recorded a disease control 67.16 and $72.46,73.34$ and $72.10,56.59$ and $56.63 \%$, respectively over untreated (Table 2). The natural incidence of blast was dominated during all the seasons. The data represent in Table 3 indicate that the treatment difference due to fungicide was statistically significant. The disease severity was $55.59,64.40$ and 62.66 which help in characterization of the new fungicide. The increased pressure in the present study was attributed to natural incidence of pathogen. During Kharif-16 and Kharif-17, Caliber application @ 3.5 ml/lit was significantly lower percent disease severity over untreated control and T1 but found statically at par with T2. In Kharif-18data showed that Caliber application @ $3 \mathrm{ml} / \mathrm{lit}$ was significantly lower disease severity percent over untreated control and T1. T2 treatment found at par with T3. The Caliber application@ @ $3.5 \mathrm{ml} /$ lit recorded a disease control 40.27 to $62.38,30.94$ to 65.09 and 38.92 to 70.52 over control during all seasons respectively.

Table 3. Efficacy of new fungicide Caliber as prophylactic spray against leaf blast of paddy under field conditions.

\begin{tabular}{|c|c|c|c|c|c|c|c|}
\hline \multirow[b]{2}{*}{ Treatments } & \multirow{2}{*}{$\begin{array}{l}\text { Dose } \\
\text { ml/lit }\end{array}$} & \multicolumn{2}{|c|}{ Kharif-16 } & \multicolumn{2}{|l|}{ Kharif-17 } & \multicolumn{2}{|c|}{ Kharif-18 } \\
\hline & & $\begin{array}{l}\text { Disease } \\
\text { Severity }\end{array}$ & $\begin{array}{l}\text { \% control over } \\
\text { untreated }\end{array}$ & $\begin{array}{l}\text { Disease } \\
\text { Severity }\end{array}$ & $\begin{array}{l}\text { \% control over } \\
\text { untreated }\end{array}$ & $\begin{array}{l}\text { Disease } \\
\text { Severity }\end{array}$ & $\begin{array}{l}\text { \% control over } \\
\text { untreated }\end{array}$ \\
\hline T1-Caliber & 2 & $\begin{array}{l}33.20 \\
(35.19)\end{array}$ & 40.27 & $\begin{array}{l}44.47 \\
(41.84)\end{array}$ & 30.94 & $\begin{array}{l}38.27 \\
(38.23)\end{array}$ & 38.92 \\
\hline T2-Caliber & 3 & $\begin{array}{l}22.14 \\
(28.06)\end{array}$ & 60.17 & $\begin{array}{l}22.79 \\
(28.50)\end{array}$ & 64.62 & $\begin{array}{l}18.47 \\
(25.43)\end{array}$ & 70.52 \\
\hline T3-Caliber & 4 & $\begin{array}{l}20.91 \\
(27.09)\end{array}$ & 62.38 & $\begin{array}{l}22.48 \\
(28.29)\end{array}$ & 65.09 & $\begin{array}{l}18.97 \\
(25.76)\end{array}$ & 69.72 \\
\hline T4-Untreated control & & $\begin{array}{l}55 \cdot 59 \\
(48.24)\end{array}$ & 0.00 & $\begin{array}{l}64.40 \\
(53.41)\end{array}$ & 0.00 & $\begin{array}{l}62.66 \\
(52.39)\end{array}$ & 0.00 \\
\hline $\mathrm{SE} \mathrm{m} \pm$ & & 1.18 & & 0.66 & & 0.99 & \\
\hline $\mathrm{CD}$ & & 3.62 & & 2.02 & & 3.06 & \\
\hline $\mathrm{CV}$ & & 7.59 & & 3.85 & & 6.26 & \\
\hline
\end{tabular}

Figures in parenthesis are Arcsine transformed. 
Table 4. Impact of Caliber fungicide as curative spray against paddy leaf blast disease.

\begin{tabular}{|c|c|c|c|c|c|c|c|}
\hline \multirow[b]{2}{*}{ Treatments } & \multirow[b]{2}{*}{$\begin{array}{l}\text { Dose } \\
\text { ml/lit }\end{array}$} & \multicolumn{2}{|c|}{ Kharif-16 } & \multicolumn{2}{|l|}{ Kharif-17 } & \multicolumn{2}{|c|}{ Kharif-18 } \\
\hline & & $\begin{array}{l}\text { Disease } \\
\text { Severity }\end{array}$ & $\begin{array}{l}\text { \% control over } \\
\text { untreated }\end{array}$ & $\begin{array}{l}\text { Disease } \\
\text { Severity } \\
\end{array}$ & $\begin{array}{l}\text { \% control over } \\
\text { untreated }\end{array}$ & $\begin{array}{l}\text { Disease } \\
\text { Severity } \\
\end{array}$ & $\begin{array}{l}\text { \% control over } \\
\text { untreated }\end{array}$ \\
\hline T1-Caliber & 2 & $\begin{array}{l}29.32 \\
(32.71)\end{array}$ & 39.10 & $\begin{array}{l}30.78 \\
(33.67)\end{array}$ & 44.71 & $\begin{array}{l}26.61 \\
(31.03)\end{array}$ & 39.77 \\
\hline T2-Calber & 3 & $\begin{array}{l}17.04 \\
(24.31)\end{array}$ & 64.61 & $\begin{array}{l}21.63 \\
(27.69)\end{array}$ & 61.15 & $\begin{array}{l}11.14 \\
(19.48)\end{array}$ & 74.78 \\
\hline T3-Caliber & 4 & $\begin{array}{l}16.50 \\
(23.85)\end{array}$ & 65.73 & $\begin{array}{l}20.48 \\
(26.87)\end{array}$ & 63.21 & $\begin{array}{l}11.48 \\
(19.78)\end{array}$ & 74.01 \\
\hline T4-Untreated control & & $\begin{array}{l}48.15 \\
(43.96)\end{array}$ & 0.00 & $\begin{array}{l}55.67 \\
(48.29)\end{array}$ & 0.00 & $\begin{array}{l}44.17 \\
(41.67)\end{array}$ & 0.00 \\
\hline SE $\mathrm{m} \pm$ & & 1.39 & & 1.12 & & 0.85 & \\
\hline $\mathrm{CD}$ & & 4.28 & & 3.44 & & 2.61 & \\
\hline CV & & 9.95 & & $7 \cdot 31$ & & 6.78 & \\
\hline
\end{tabular}

Figures in parenthesis are Arcsine transformed.

As expected, the Caliber fungicide sprayed after appearance of the disease symptoms exhibited good control of the blast. The consistent results were observed in all the three trials with application of Caliber @ 3 and 4 ml/lit recorded 17.04 and 16.50; 21.63 and 20.48 and 11.14 and 11.48 disease severities during Kharif-16, Kharif-17 and Kharif-18. The percent recover varied from range 39.10 to 65.73 , 44.71 to 63.21 and 39.77 to 74.78 over control during Kharif-16, Kharif-17 and Kharif-18.

The present investigation proves the efficacy of a fungicide Caliber for management of sheath blight and blast diseases of paddy. Application of Caliber @ $3 \mathrm{ml} /$ lit and $4 \mathrm{ml} /$ lit has extremely effective to control sheath blight and blast diseases of paddy. If we analyse the data obtained from the trials, it can be concluded that both the treatments i.e. Caliber@ $3 \mathrm{ml} /$ lit and $4 \mathrm{ml} /$ lit having more or less the same results. Hence, we are recommending to use $\mathrm{T}_{3}$ i.e. Caliber @ 3ml/lit as a fungicide for the management of Sheath blight and Blast on Paddy.

\section{Conflict of interest statement}

Authors declare that they have no conflict of interest.

\section{References}

Ahmad Ali Shahid, Muhammad Shahbaz and
Muhammad Ali A Comparative Study of the Commercially Available Fungicides to Control Sheath Blight of Rice J Plant Pathol Microb 2014, 5:4.

Kutubuddin A. Molla, Subhasis Karmakar, Johiruddin Molla, Prasad Bajaj, Rajeev K. Varshney, Swapan K. Datta, and Karabi Datta Understanding sheath blight resistance in rice: the road behind and the road ahead Plant Biotechnol J. 2020 Apr; 18(4): 895-915.

Talluri Bhaskar Rao, Ramakrishna Chopperla, Ramesh Methre, E Punniakotti, V Venkatesh, B Sailaja, M Raghurami Reddy, Arra Yugander, G S Laha, M Sheshu Madhav, R M Sundaram, D Ladhalakshmi, S M Balachandran, S K Mangrauthia 2019. Pectin induced transcriptome of a Rhizoctonia solani strain causing sheath blight disease in rice reveals insights on key genes and RNAi machinery for development of pathogen derived resistance Plant Mol Biol 2019, 100(1-2):59-71

Kouzai Y, Kimura M, Watanabe M, Kusunoki K, Osaka D, Suzuki T, Matsui H, Yamamoto M, Ichinose Y, Toyoda K, Matsuura T. Salicylic acid- dependent immunity contributes to resistance against Rhizoctonia solani, a necrotrophic fungal agent of sheath blight, in rice and Brachypodium distachyon. new phytologist. 2018 Jan;217(2):771-83.

\section{How to cite this article:}

Nalawade, N., Kumbhar, A., Raskar, A., Baravkar, A., 2020. Study of efficiency and control of paddy sheath blight and leaf blast by caliber fungicide. Int. J. Curr. Res. Biosci. Plant Biol. 7(8), 12-15.

doi: https://doi.org/10.20546/ijcrbp.2020.708.002 